\title{
DIDEMNIN B : COMPARATIVE STUDY AND CONFORMATIONAL APPROACH IN SOLUTION.
}

\author{
B. BANAIGS ${ }^{2}$, G. JEANTY ${ }^{\mathbf{a}}$, C.FRANCISCO ${ }^{*}$, P.JOUIN ${ }^{\mathbf{b}}$, J. PONCET ${ }^{\mathbf{b}}$,

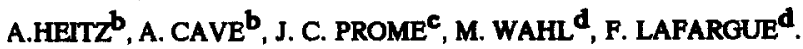

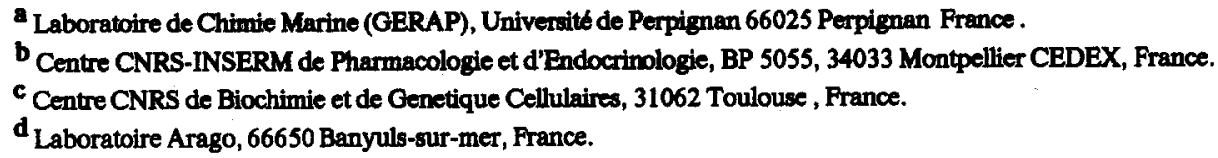

(Received in Belgium 12 October 1988)

\begin{abstract}
A comparative study of isodidemnine-1 and didemnin $B$ is presented using spectroscopic methods, partial degradation and partial synthesis. This leads to the conclusion of the presence of a single depsipeptide, namely didemnin B, with $(3 S, 4 R, 5 S)$ isostatine instead of the previous statine residue. An attempt to determine the whole conformation in solution of didemnin $B$ by using $2 D-N M R$ is also described .
\end{abstract}

Over the last decade, the widely-distributed order of Aplousobranchiata (Phylum Chordata, Class Ascidiacea), one of the colonial form of Urochordata, has been the object of intense chemical scrutiny by several research groups [1]. The initial interest for the family of Didemnidae - probably derivated from the family of Polycitoridae in the course of evolution [2] was prompted by the potent activity found against viruses and tumor cells [3] from a Carribean tunicate (Trididemnum sp. possibly Trididemnum cyanophorum) [4]. This led to the isolation of a new class of novel cyclic depsipeptides called the di-

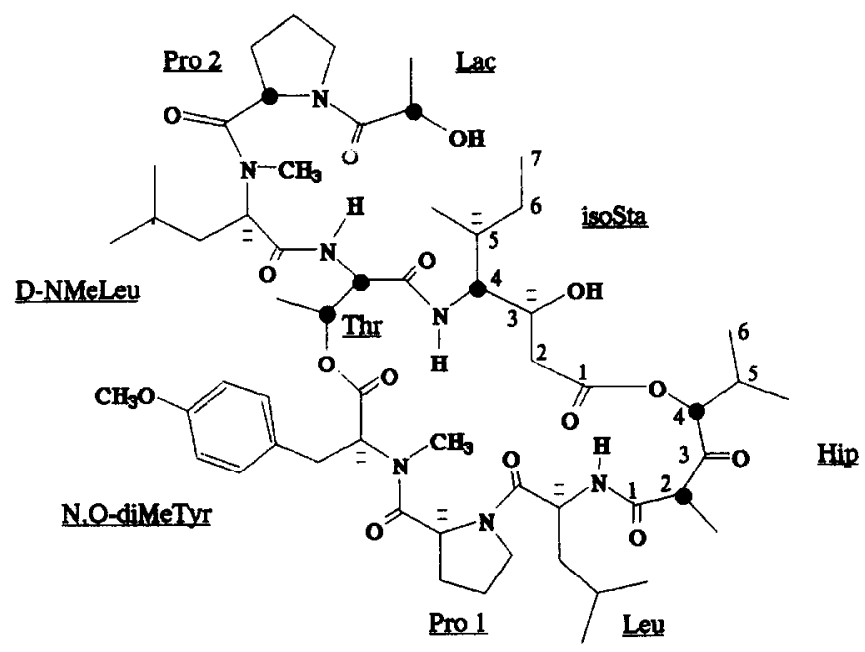

Figure 1 : Structure of Didemnin B

demnins [5], and to numerous reports of pharmacological studies of these new agents [6]. More recently, the structure of another didemnin was published [7] and the structure of the former didemnin B revised. [8]

Along with our continued interest in the novel natural products chemistry of marine organisms, we have begun a systematic study of Didemnidae with respect to their chemical defenses. Various metabolites from marine tunicates have been shown in our lab [9], to possess antimicrobial, cytotoxic or antiparasitory properties, in agreement with the need for softbodied organisms to develop the art of chemicals (from lipids to peptides) against their predators. During these studies, we 
have worked on Trididemnum cyanophorum (Guadaloupe) which was known to be the host of an unicellular cyanophyta (Synechocystis trididemmi) [10], and found didemnin-like products. Our first results [11] convinced us that the situation was unclear between the various clcely related species of Carribean Trididemum (cyanophorum, solidum or palmae), and between the various deseribed peptides (isodidemnin-1, former didemnin $B$ or the revised structure). Therefore, we decided to present a complete study, inctuding information and results obtained by comparison of isodidemnin- 1 and our major product. Considering the high activity of these agents, we have also undertaken efforts to determine the drug conformation in solution, using 2D-NMR means. [12,13]

The mostabundant compound from Trididemnun cyanophorum (harvested by Scuba techniques near "llet Pigeon" = Cousteau's reservation) was readily identfied as a peptide by mass opectrometry (see experimental). Its close relationship with didemnin B was based on ${ }^{1} \mathrm{H}$ NMR, including 2D-NMR (table 1), and on GC/MS of the heptafluorobutyl propyl ester derivatives of the constituent amino acids. All these results were in agreement with those already described by Rinehart. From a pharmacological point of view, we found lesser activities $\left(\mathrm{ID}_{50}=0.19 \mathrm{nM}\right.$ ) during in vitro B16 melanoma and P388 screenings, but also lower toxicity during in vivo P388 tests, as some mice were found to survive.

Table 1: ${ }^{1 H-13 C ~ N M R ~ D A T A ~}(360 / 90 \mathrm{MHz})$

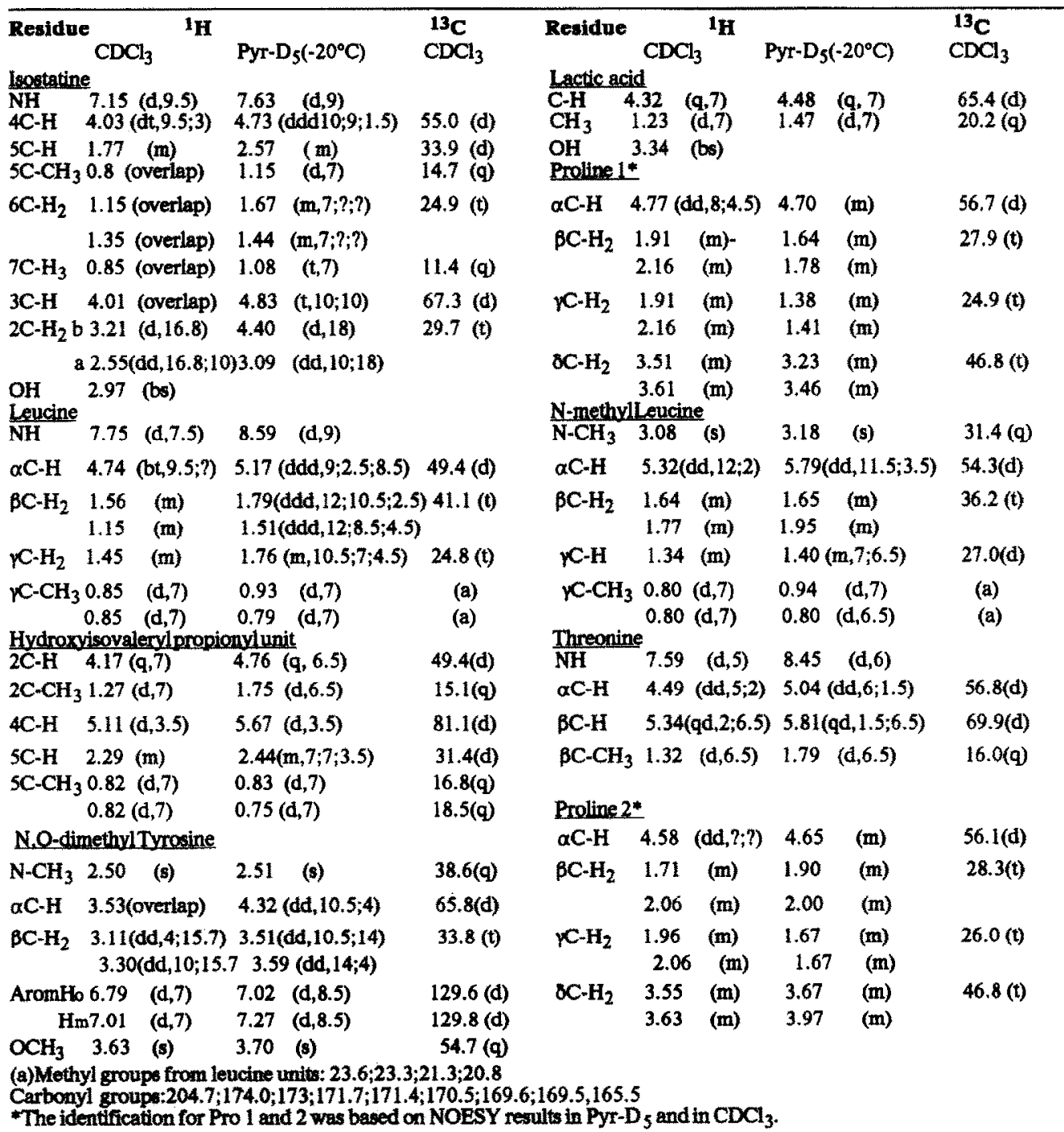


Structure elucidation: The most interesting structural fact was displayed by $2 \mathrm{D}-\mathrm{NMR}\left({ }^{1} \mathrm{H}-{ }^{1} \mathrm{H}\right.$ COSY) in $\mathrm{C}_{6} \mathrm{D}_{6}$, where a conspicuous triplet was observed corresponding to a methyl group belonging to an isostatine (isoSta) instead of statine. This result was confirmed by ${ }^{1} \mathrm{H}-{ }^{13} \mathrm{C}$ heteronuclear COSY $2 \mathrm{D}-\mathrm{NMR}$ (table 1), leading to the final macrocyclic structure presented in figure 1 .

Next, we decided to study the stereochemistry of the various residues, except for the Hip (hydroxyisovaleryl propionyl unit) already revised by M. M. Joullie [14]. We used Marfey's method [15] in combination with HPLC to determine the absolute configuration of amino acids from our product after hydrolysis with $6 \mathrm{~N}$ hydroctiloric acid, in comparison with available commercial samples or synthetic ones (isoSta for instance). So, we were able to reach our aim [16], eliminating several cases like $\mathrm{D}$ allothreonine which had been found to be a good candidate in regard of both scalar and NOE couplings data. All our results were in complete agreement with those recently described: $L$ configuration for MeTyr(Me), Leu, Pro and Thr, D configuration for MeLeu and (3S,4R,5S) for isoSta. Taking into account the revision of the structure for didemnin B by Rinehart [17], it was clear that we had isolated the same product.

On the contrary, isodidemnin-1 looked different with its positive optical rotation $\left(+70^{\circ}\right)$ and its $(3 \mathrm{~S}, 4 \mathrm{R}, 5 \mathrm{R})$ or (3R,4S,5S) isoSta [7]. As isodidemnin-1 was also a very potent drug, our first idea was to study both depsipeptides in order to compare their conformation in solution. After the first spectroscopic analysis, we suspected that isodidemnin-1 and didem$\operatorname{nin} B$ were in fact the same product.

In order to confidently prove it, we focused our attention to a fragment of didemnin containing the isostatyl residue and undertook the synthesis of this fragment. The cyclodepsipeptide didemnin B containing two alkali-labile bonds, the specific cleavage of these bonds should lead to the peptide Lac - Pro - DMeLeu - Thr - isoSta. Parallel alkaline hydrolysis of isodidemnin-1 and of our sample, followed by methylation with diazomethane [7], gave a complex mixture from which only the expected peptide was identified after isolation by silica gel chromatography $\left(\mathrm{CH}_{2} \mathrm{Cl}_{2} / \mathrm{MeOH} 92 / 8\right)$ followed by reverse phase HPLC. The natural peptide from both origins gave the same HPLC retention time and identical ${ }^{1} \mathrm{H}$ NMR spectra. In an attempt to unambigously assign the stereochemistry of the isoSta residue, this peptide was compared first with synthetic Lac Pro - D MeLeu - Thr - (3R,4S,5S) isoSta -OMe related to the presomptive evidences previously produced and then with the synthetic analogue in which $(3 R, 4 S, 5 S)$ isoSta was replaced by the $(3 S, 4 R, 5 S)$ diastereoisomer in agreement with this study and the recent revised structure for didemnin B. [8]

The peptide sequence was readily produced by coupling isoStaOEt to Lac - Pro - DMeLeu - Thr in order to minimize the number of steps after the introduction of isoSta (the most inaccessible of the five starting residues). Furthermore, we deliberately chose to couple the readily obtained ethyl ester of isoSta, instead of the required methyl ester, in order to submit both synthetic and natural compounds to the same experimental conditions previous to the final purification (i.e. saponification followed by diazomethane methylation). The BOP reagent [18] was successfully employed to prepare the dipeptides Lac-ProOtBu and DMeLeu-ThrOMe. Subequent coupling of both segments was best achieved, but only in acceptable yield, by using BOP-Cl as previously described [19], assuming that segment coupling on a prolyl residue would produce minimum epimerisation. The $(3 S, 4 R, 5 S)$ isomer of isoSta was obtained from $D$ allo Ile and the $(3 R, 4 S, 5 S)$ isomer from lle following a reported procedure[20]. Since this exotic amino acid was located at the carboxy terminus of the target sequence, we used BOP activation for coupling Lac-Pro-DMeLeu-Thr with isoSta in order to minimize racemisation [1 8]. Saponification of the carboxyl group in the final peptide, followed by $\mathrm{CH}_{2} \mathrm{~N}_{2}$ treatment, produced the expected sequence. Chromatographicpurification afforded the pure methyl ester protected peptide in $40 \%$ overall yield. Only the synthetic compound built up from the (3S,4R,5S) isoSta had a close spectroscopic (table 2) identity with the natural fragments. As expected from the presence of $\mathrm{N}$-alkyl amino acids in this sequence, several minor rotamers were visible in the NMRspectrum of both synthetic and natural peptides. The diastereomeric purity was ascertain from HPLC analysis. All these results confirmed the (3S,4R,5S) configuration for isoSta in both natural depsipeptides, thus providing a confident proof for the reality of a single depsipeptide : cidem$\operatorname{nin} \mathbf{B}$.

Conformational study: Then, we undertook an evaluation of the conformation of Didemnin B in solution [21] by means of 2D-NMR techniques (NOESY mainly). Due to the size of the peptide, it has been necessary to perform NOESY at $253^{\circ} \mathrm{K}$ in 
Table 2 : ${ }^{1}$ H NMR date for the major rotener of peptiden Lac-Pro-DMeLen-Thr-isosta-OMe (DMso d 6 )

\begin{tabular}{|c|c|c|c|c|c|c|}
\hline \multirow{3}{*}{$\begin{array}{l}\text { Residues } \\
\text { Lactic acid } \\
1 \mathrm{C}-\mathrm{H} \\
\mathrm{IC}_{-} \mathrm{CH}_{3}\end{array}$} & \multicolumn{3}{|c|}{ with $(3 R, 48,5 S)$ isosta } & \multicolumn{3}{|c|}{ with $(38,4 R, 5 s)$ ieoste } \\
\hline & 8 & mult. & $\mathbf{J}$ & 8 & mult. & J \\
\hline & $\begin{array}{l}4.33 \\
1.16\end{array}$ & $\underset{d}{d q}$ & $\begin{array}{l}6.4 ; 6.8 \\
6.4\end{array}$ & $\begin{array}{l}4.33 \\
1.16\end{array}$ & $\begin{array}{l}t \\
d\end{array}$ & $\begin{array}{l}6.8 \\
6.8\end{array}$ \\
\hline $\begin{array}{l}\text { OH } \\
\text { Proline }\end{array}$ & 4.93 & d & 6.8 & 4.92 & d & 6.8 \\
\hline$\alpha C-H$ & 4.74 & dd & $7.3 ; 6.3$ & 4.74 & bt & $7.3+?$ \\
\hline $\mathrm{BC}-\mathrm{H}_{2}$ & $2.22-1.67$ & $\mathbf{m}$ & & $2.21-1.65$ & $\mathbf{m}$ & \\
\hline $\mathrm{YC}-\mathrm{H}_{2}$ & $2.01-1.87$ & $\mathbf{m}$ & & $2.01-1.89$ & $\mathbf{m}$ & \\
\hline $\begin{array}{l}8 \mathrm{C}-\mathrm{H}_{2} \\
\mathrm{~N} \text {-methyl Leucine }\end{array}$ & 3.78-3.48 & $\mathbf{m}$ & & $3.77-3.48$ & m & \\
\hline $\mathrm{N}-\mathrm{CH}_{3}$ & 3.02 & $\mathbf{s}$ & & 3.02 & s & \\
\hline$\alpha C-H$ & 5.06 & dd & $4.4 ; 10.7$ & 5.05 & dd & $4.4 ; 10.8$ \\
\hline $\mathrm{BC}-\mathrm{H}_{2}$ & $1.67-1.65$ & m & & $1.66-1.59$ & m & \\
\hline$\gamma \mathrm{C}-\mathrm{H}$ & 1.40 & m & & 1.38 & $\mathbf{m}$ & \\
\hline $\begin{array}{l}\mathrm{K}-\mathrm{CH}_{3} \\
\text { Threonine }\end{array}$ & $0.89-0.82$ & d & 6.2 & $0.89-0.82$ & d & 6.2 \\
\hline $\mathbf{N}-\mathbf{H}$ & 7.31 & d & 9.8 & 7.31 & d & 7.8 \\
\hline$\alpha C-H$ & 4.16 & dd & $9.8 ; 4.4$ & 4.14 & dd & $7.8 ; 4.9$ \\
\hline$B C \cdot H$ & 3.99 & $\mathbf{m}$ & & 3.99 & In & \\
\hline $\mathrm{BC}-\mathrm{CH}_{3}$ & 1.02 & d & 6.4 & 1.04 & d & 6.3 \\
\hline $\begin{array}{l}\text { OH } \\
\text { isostatine }\end{array}$ & 4.86 & d & 7.3 & 4.90 & $d$ & 6.8 \\
\hline $\begin{array}{l}\mathrm{N}-\mathrm{H} \\
4 \mathrm{C}-\mathrm{H} \\
5 \mathrm{C}-\mathrm{H} \\
5 \mathrm{C}-\mathrm{CH}_{3}\end{array}$ & $\begin{array}{l}7.18 \\
3.65 \\
1.74 \\
0.79\end{array}$ & $\begin{array}{l}\mathrm{d} \\
\mathrm{m} \\
\mathrm{m} \\
\mathrm{d}\end{array}$ & 6.3 & $\begin{array}{l}7.33 \\
3.77 \\
1.85 \\
0.81\end{array}$ & $\underset{\mathrm{m}}{\mathrm{d}}$ & 6.3 \\
\hline $6 \mathrm{C}-\mathrm{H}_{2}$ & $1.50-1.02$ & $\mathbf{m}$ & & $1.20-1.09$ & $\mathrm{~m}$ & \\
\hline $7 \mathrm{C}-\mathrm{CH}_{3}$ & 0.83 & $\mathbf{t}$ & 6.4 & 0.81 & $\mathbf{t}$ & 6.4 \\
\hline $\begin{array}{l}3 \mathrm{C}-\mathrm{H} \\
2 \mathrm{C}-\mathrm{H}_{2}\end{array}$ & $\begin{array}{l}3.86 \\
2.55-2.12\end{array}$ & $\underset{d A B}{m}$ & $15.1 ; 2.4 ; 10.2$ & $\begin{array}{l}3.81 \\
2.60-2.12\end{array}$ & $\mathrm{dAB}$ & $15.1 ; 2 ; 9.7$ \\
\hline $\begin{array}{l}\text { OH } \\
\text { OMe }\end{array}$ & $\begin{array}{l}4.92 \\
3.58\end{array}$ & $\begin{array}{l}\mathrm{d} \\
\mathrm{s}\end{array}$ & 7.3 & $\begin{array}{l}4.92 \\
3.58\end{array}$ & $\begin{array}{l}\text { d } \\
\text { s }\end{array}$ & 6.8 \\
\hline
\end{tabular}

order to see the negative enhancements, as nothing could be observed at room temperature - ROESY techniques were also employed (mainly in $\mathrm{C}_{6} \mathrm{D}_{6}$ ) at room temperature and the observed positive enhancements were found to be consistent with the NOESY data -. The molecule looked rigid under the experimental conditions, as ${ }^{1} H$ NMR data in several solvents had shown didemnin B to present one set of well-resolved signals. For instance, the large differences (in all the solvents) concerning chemical shifts and vicinal coupling constants between $3 \mathrm{C}-\mathrm{H}$ and the geminal diastereotopic isoSta protons $2 \mathrm{C}-\mathrm{Ha}$ and $2 \mathrm{C}-\mathrm{Hb}$, were indicative of the rigidity of the backbone macrocycle. Thus, its principal conformation was much easier to determine than expected. Having established the unequivocal assignment of the $\mathrm{NMR}$ spectra (in $\mathrm{CDCl}_{3}, \mathrm{C}_{6} \mathrm{D}_{6}$ and Pyridine$D_{5}$ ) of our depsipeptide, the NOESY data allowed us to confirm the amino acids sequence, except for the ester bond linkages (Scheme 1).

Also, some internal enhancements were displayed during these experiments, mainly in Thr (between $\mathrm{NH}$ and $\mathrm{C} \beta \mathrm{H} / \mathrm{C \beta CH}$ ) and isoSta (between $\mathrm{NH}$ and $\mathrm{C} 3 \mathrm{H} / \mathrm{C} 2 \mathrm{Hb} / \mathrm{CSCH}_{3}$, between $\mathrm{C4H}$ and $\mathrm{C}_{6} \mathrm{CH}_{3}$ ). Some conformational information was obtained with the help of scalar coupling constants (acheme 2). A trans conformation for the Pro 1-MeTyr(Me), Pro 2-DMeLeu and Thr-isoSta peptidic bonds was confidenthy assigned as NOE enhancements oceurred between NH or $\mathrm{NCH}_{3}$ and the $\alpha$ proton of the preceding amino acid. A similar conclusion was reached for Pro 1-Leu and Pro 2-Lac amidic bonds due to the NOEs between both protons $8 \mathrm{CH}_{2}$ of Pro 1 and Pro 2 respectively with $\alpha-\mathrm{CH}$ Leu and $\alpha-C H$ Lac.. A trans conformation was confidently given to the bond Hip-Leu, based on a valuable NOE enhancement between C2H Hip and NH Leu. Though the NOE data did not directly yield information about the DMeLeu-Thr peptidic bond, it was necessary to have a trans conformation to explain the important intensity of NOE enhancement between $\mathrm{NCH}_{3} \mathrm{DLeu}$ and $\mathrm{NHThr}$. This NOE result, indicating 
Scheme 1 : NOE reaults (from NOBSY and ROBSY experiments).

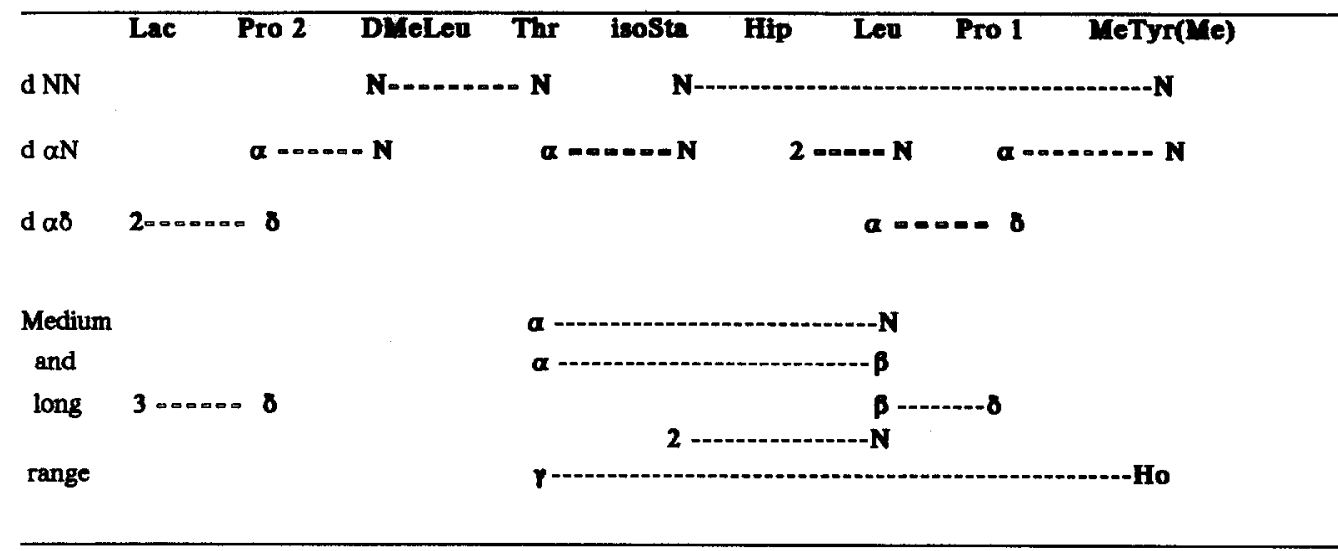

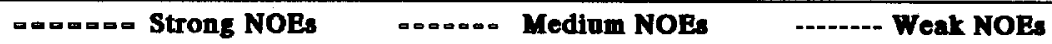
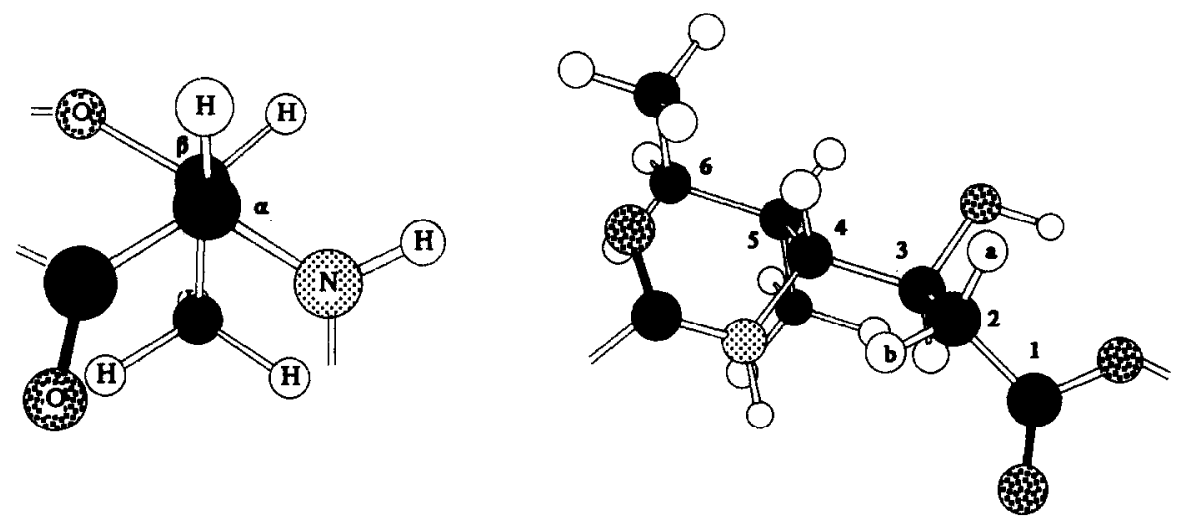

Scheme 2 : Threonine and ( $3 S, 4 R, 5 S$ ) icostatine conformations

Table 3: NH/ $\mathrm{CCH}$ variations according to solvents and to temperature

\begin{tabular}{|c|c|c|c|c|c|c|c|c|c|}
\hline Residue & $\mathrm{CDCl}_{3}$ & Pyr-D & $\Delta 8$ & $\begin{array}{l}\mathrm{CDCl}_{3}+ \\
\text { drop } \mathrm{MeOH}\end{array}$ & $\Delta 8$ & $\begin{array}{l}345^{\circ} \mathrm{K} \\
\text { Pyr- } \mathrm{D}_{5}\end{array}$ & $\begin{array}{l}253^{\prime} \mathrm{K} \\
\text { Pyr-D5 }\end{array}$ & $\Delta 8$ & DMSO \\
\hline $\begin{array}{l}\text { NH iSta } \\
\text { NH Leu } \\
\text { NH Thr } \\
\mathrm{NCH}_{3} \text { Leu }\end{array}$ & $\begin{array}{l}7.15 \\
7.75 \\
7.59 \\
3.08\end{array}$ & $\begin{array}{l}7.56 \\
8.47 \\
8.25 \\
3.24\end{array}$ & $\begin{array}{l}0.41 \\
0.72 \\
0.66 \\
0.16\end{array}$ & $\begin{array}{l}7.28 \\
7.81 \\
7.64 \\
3.19\end{array}$ & $\begin{array}{l}0.13 \\
0.06 \\
0.05 \\
0.11\end{array}$ & $\begin{array}{l}7.56 \\
8.47 \\
8.25 \\
3.24\end{array}$ & $\begin{array}{l}7.67 \\
8.63 \\
8.49 \\
3.18\end{array}$ & $\begin{array}{l}0.11 \\
0.16 \\
0.24 \\
0.06\end{array}$ & $\begin{array}{l}6.92 \\
7.85 \\
7.77 \\
3.05\end{array}$ \\
\hline $\mathrm{NCH}_{3} \mathrm{Tyr}$ & 2.50 & 2.64 & 0.14 & 2.55 & 0.05 & 2.64 & 2.51 & 0.13 & 2.50 \\
\hline$\alpha \mathrm{CH}$ Tyr & 3.53 & 4.20 & 0.67 & $?$ & $?$ & 4.20 & 4.32 & 0.12 & 4.06 \\
\hline$\alpha \mathrm{CH}$ Pro 1 & 4.77 & 4.75 & 0.02 & 4.87 & 0.10 & 4.75 & 4.70 & 0.05 & 4.63 \\
\hline $\begin{array}{l}\alpha \text { CH Leu } \\
\text { H2 Hip } \\
\text { H4 Hip }\end{array}$ & $\begin{array}{l}4.74 \\
4.17 \\
5.11\end{array}$ & $\begin{array}{l}5.19 \\
4.72 \\
5.65\end{array}$ & $\begin{array}{l}0.45 \\
0.55 \\
0.54\end{array}$ & $\begin{array}{l}4.80 \\
4.03 \\
4.99\end{array}$ & $\begin{array}{l}0.06 \\
0.14 \\
0.12\end{array}$ & $\begin{array}{l}5.19 \\
4.72 \\
5.65\end{array}$ & $\begin{array}{l}5.17 \\
4.76 \\
5.67\end{array}$ & $\begin{array}{l}0.02 \\
0.04 \\
0.02\end{array}$ & $\begin{array}{l}4.73 \\
3.96 \\
4.94\end{array}$ \\
\hline$\alpha \mathrm{CH}$ isoSta & 4.03 & 4.70 & 0.67 & 3.90 & 0.13 & 4.70 & 4.73 & 0.03 & 3.82 \\
\hline$\alpha \mathrm{CH}$ Thr & 4.49 & 5.07 & 0.58 & 4.54 & 0.05 & 5.07 & 5.04 & 0.03 & 4.35 \\
\hline aCHMeLeu & 5.32 & 5.80 & 0.48 & 5.39 & 0.07 & 5.80 & 5.79 & 0.01 & 5.05 \\
\hline $\begin{array}{l}\alpha \mathrm{CH} \text { Pro } 2 \\
\text { CH Lac }\end{array}$ & $\begin{array}{l}4.58 \\
4.32\end{array}$ & $\begin{array}{l}4.72 \\
4.53\end{array}$ & $\begin{array}{l}0.14 \\
0.21\end{array}$ & $\begin{array}{l}4.70 \\
4.47\end{array}$ & $\begin{array}{l}0.12 \\
0.15\end{array}$ & $\begin{array}{l}4.72 \\
4.53\end{array}$ & $\begin{array}{l}4.65 \\
4.48\end{array}$ & $\begin{array}{l}0.07 \\
0.05\end{array}$ & $\begin{array}{l}4.35 \\
4.04\end{array}$ \\
\hline
\end{tabular}


a close spatial proximity, could be only arranged for such a trans conformation, with a special spatial position for the $\mathrm{NCH}_{3}$, leading to $\mathrm{a} \beta$ or $\gamma$ turn in the dangting tripeptide fragment that placed the DMeLeu, Pro 2 and Lacresidues outside the cycle. The trans peptide bond conformation, already mentioned involving Pro 2 and DMeLeu, increased this arrangement. A $\beta$ turn [22], with DMeLeu and Pro 2 occupying the corner positions, was chosen to explain the low-field chemical shift of $\alpha \mathrm{CH}$ DMeLeu $(\delta=5.80 \mathrm{ppm})$ due to coplanarity with CO Pro 2, with a likely hydrogen bond between the CO Lac (i) and the NH Thr $(i+3)$ as a conformational consequence. These results suggested a general shape for the molecule.

During these studies, we noted some spatial effects accross the ring - NH Leu- $\alpha$ CH Thr, NH Leu-2CHb isoSta, $\alpha \mathrm{CH}$ Thr- $\beta \mathrm{CH}$ Leu, $2 \mathrm{CHb}$ isoSta- $\alpha \mathrm{CH}$ Thr -, indicating an internal NH Leu and the possibility of an unexpected arrangement for the isoSta residue. In order to confirm those points, some parameters (temperature, solvents) of COSY experiments were changed (table 3) . Interestingly, the effects involving the NH groups of Leu and isoSta are almost temperature independent $\left(<0.002 \mathrm{ppm} /{ }^{\circ} \mathrm{K}\right.$ in the range from 253 to $\left.345^{\circ} \mathrm{K}\right)$, in agreement with an expected internal orientation [23] that could be related to strong hydrogen-bridges inside the cycle. The low solvatation for both NH isoSta and NH Leu was also pointed out, in accord with two possible hydrogen-bonds from NH isoSta to CO Leu and CO MeTyr(Me). This rationalized the NOE enhancements $\beta \mathrm{CH}$ Leu- $\alpha \mathrm{CH}$ Thr and NH Leu-2CHb isoSta. With the support of an internal NH Leu and of isoSta (already organised, scheme 2), we returned to the Hip in order to reach conformational conclusions as NOE results were lacking for this residue. To rationalise this lack of long distance spin interactions, one of its carbonyl groups (3C) had to be oriented perpendicular to the medium plane of the cycle to look after the whole conformation for the rest of the cycle (accordingly to the whole NOE results). That conformation for the molecule allowed us to explain the turning up of the peptidic propagation in the cycle, as a bend was found out from isoSta to Leu with Hip occupaying the corner position. As the Hip residue is not an amino acid, 9 atoms are involved in this bend, leading to an intermediate turn between $\beta$ ( 10 atoms) and $\gamma$ ( 7 atoms). Finally, that bend (CO isoSta-Hip-NH Leu) and the extended row * Leu-Pro 1-MeTyr(Me) confirmed the conclusion that the other ester bond (CO MeTyr(Me)-O Thr) was involved in a second turn to build the ring, the CO Pro 1 being in a perpendicular orientation to the medium plane (figure 2).

In conclusion, we should like to point out the following points: (a) it is obvious that all didemnin B-like depsipeptides described until now from Carribean tunicates, are in fact the same one, namely didemnin $B$ - with $(3 S, 4 R, 5 S)$ isoSta instead of Sta - (b) the NMR conformational analysis showed NH Leu and NH isoSta to be oriented inward (c) the $\beta$ turn conformation for the side chain that could play a part in the drug-receptor interactions in regard to the different averages of activity from didemnin $B$ to didemnin $A$ (which is without such an organised side chain). However, didemnin $A$ is also a very potent drug indicating that the conformational picture of the cycle is, by far, the most valuable knowledge (d) the overall organisation of isoSta with a free hydroxyl group that could be related with the activity of such compounds according to the protease inhibitory effect of pepstatin (which is dependent on the free OH group of Sta [24], with the same absolute configuration for the carbon bearing this $\mathrm{OH}$ functionality in pepstatin and didemnin B) and the antineoplastic activity of dolastatin 10, [25]

The results of our study led to the conclusion that didemnin $B$ in solution looked like an isolated rather that a solvated molecule, from a conformational point of view. The resulting overall molecular shape (or at least, the main one that dominated the equilibrium) was found to assume a conformational constancy from $\mathrm{CDCl}_{3}$ to DMSO. The most surprising fact concerned the tail Lac-Pro 2-DMeLeu-Thr where a similar conformation was found in DMSO and in apolar solvents **. A likely explanation of such an effectcould be reiated to the presence of a proline rigidifier and a collection of sterically demanding sidechains all around this tail (aromatic ring, Leu, isoSta). We are currently undertaken NMR additional experiments in protic solvents for $\mathrm{a}$ better understanding of this stable conformation that could be related to the lipophilic nature of didemnin $B$.

* This random arrangement was based on the great intensity of NOEs for MeTyr(Me), Leu, Pro 1 and on the vicinal NH/ $\alpha$ CH scalar coupling $(3 \mathrm{~J}=9.5 \mathrm{~Hz})$ for Leu.

** See the overall integrity of chemical shifts in table 3. More, actual ID NOE experiments in DMSO indicate the presence of effects between $\mathrm{NCH}_{3} \mathrm{Leu} / \mathrm{NH} \mathrm{Thr}, \mathrm{CH}_{3} \mathrm{Lac} / \mathrm{CCH}_{2} \mathrm{Pro} 2$ and $\alpha \mathrm{CH} \mathrm{Pro} 2 / \mathrm{NCH}{ }_{3} \mathrm{Leu}$, in agreement with an overall similar conformation for this fragment in any solvents 
Pigure 2 : Computer-generated drawing of Didemin $B$ in colution. Most of hydrogens are omitted for clarity.

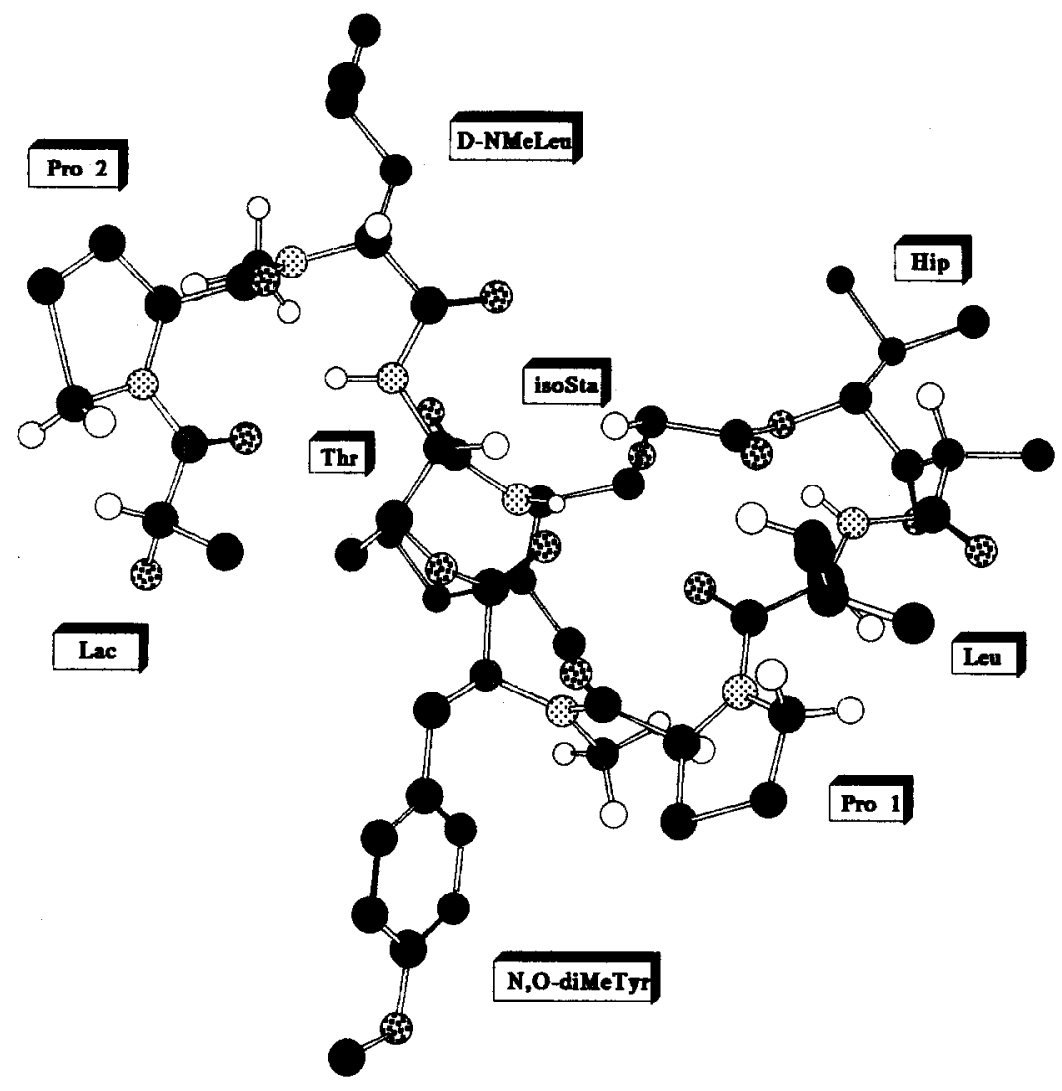




\section{EXPERIMENTAL}

General: IR and UV spectra were recorded respectively on a Perkin Elmer model 621 and a Pye-Unicam model SP8/300 spectrophotometers. Optical rotations were recorded on a Rousel Jouan polarimeter, model T71, using a $0.5 \mathrm{~cm}$ microcell. ${ }^{1} \mathrm{H}$ and ${ }^{13} \mathrm{C} \mathrm{NMR}$ spectra (1D or 2D) were recorded on a $360 / 90 \mathrm{MHz}$ Bruker WM-360 spectrometer. Melting points were determined using a Buchi melting-point apparatus. Specific optical rotations were measured on a Schmidt and Haensch Polartronic D apparatus. GC/MS experiments and FAB mass epectra were obtatned on a ZAB HS (VG - analytical, Manchester, UK) operating at $8 \mathrm{keV}$ accelerating voltage. For FAB/MS, a Xenon beam of $8 \mathrm{keV}$ was focused on the target covered with $\mathrm{Ca}, 1 \mathrm{mg}$ of sample dissolved into $2 \mathrm{ml}$ of a 1:1 mixture of glycerol and thioglycerol. For GCMS experiments, a combined EI/CI source was used. The electron energy was $70 \mathrm{eV}$ (BD) and $50 \mathrm{eV}$ (CI). Scan speed was 1 sec/decade. A $0.32 \mathrm{~mm}$ (i.d.) $\times 30$ m fused silica column, coated with OV 1 was used. Helium was the carrier gas. BOP reagent (Benzotriazolyloxy - tris (dimethylamino) phosphonium hexafluoro-phosphate) was obtained from Sempa-Chimie. Amino acids derivatives were of the L form and were purchased from Bachem or Novabiochem. HPLC analysis were performed using Ultrasphere ODS Beckman $10 \times 250 \mathrm{~mm}$ (column A) or Ultrasphere ODS Beckman 4.6x150 (column B).

Abbreviations and symbols follow the recommendations of IUPAC-IUB Joint Commission on Biochemical Nomenclature (Eur. J. Biochem. 1984, 9, 138). In addition the following abbreviations are used: BOP: (1H-1,2,3-benzotriazol-1-yloxy)tris(dimethylamino)-phosphonium hexafluoro phos phate; BOP-Cl : N,N'-bis-(2-oxo-3-oxazolidinyl)-phosphonic chloride; COSY: two dimensional correlated spectroscopy ; DIEA: diisupropylethylamine; isoSta : 4-amino-3-hydroxy-5-methyl heptanoic acid; Lac : L - lactic acid; NOESY : two dimensional nuclearOverhauser enhancement spectroscopy; Sta : 4-amino-3hydroxy-6-methylheptanoicacid; TFA : trifluoroacetic acid,

Collection.extraction : Trididemnum cyanophorum was collected at "Tlet Pigeon" (Guadaloupe) in March 1985. After collection, samples were stored in ethyl alcohol. The alcohol was decanted and the whole animal was repeatedly extracted with $50 \%$ $\mathrm{CH}_{2} \mathrm{Cl}_{2}$ in $\mathrm{MeOH}$. The resulting dark green solutions were evaporated to dryness under vacuum and the residue was diluted with water, transferred to separatory funnels and extracted with ether $(3 \times 1$ iter). The organic layer was evaporated to yield a $2.5 \mathrm{~g}$ extract. The aqueous phase was then extracted with $n$-butanol $(3 \times 1$ liter). The solvent was removed to give a green solid which was extracted with $\mathrm{CH}_{2} \mathrm{Cl}_{2}$ ( $3 \times 1$ liter). Evaporation of the organic solutions yielded $1 \mathrm{~g}$ of a dark brown solid.

Chromatographicprocedures: The $1 \mathrm{~g} \mathrm{CH}_{2} \mathrm{Cl}_{2}$ extract was loaded onto a $\mathrm{LH}-20$ column which was packed in $\mathrm{MeOH}$ and elution was allowed to proceed. Four fractions were collected and the content of each fraction was evaluated by TLC (reverse phase $\mathrm{Cl}$, $\mathrm{MeOH} / \mathrm{H}_{2} \mathrm{O} 9 / 1$ or $7 / 3$ ), using chlorine vapor as visualization reagent. The main fraction (634 $\mathrm{mg}$ ) was loaded on a Lowbar silica gel column which was eluted in step gradient fashion with a MeOH/CH ${ }_{2} \mathrm{Cl}_{2}$ fraction. The main cyclodepsipeptide was contained in the $97 / 3 \mathrm{CH}_{2} \mathrm{Cl}_{2} \mathrm{MeOH}$ fraction. For data accumulation and testing, it was further purified by reverse phase HPLC, monitoring by differencial refractometers. Essentially pure compound was obtained as a white amorphous solid ( $50 \mathrm{mg}$ ) on a C18 reverse phase column $(50 \times 1 \mathrm{~cm})$ with MeOH/Water $7 / 3$ as solvent for this purification.

Phyvicaldata : UV(MeOH):209(20000),223(14800),277(7050),284(6090);[ $\alpha]_{D}=-70^{\circ}\left(\mathrm{co} .06, \mathrm{CHCl}_{3}\right)$

$\mathrm{IR}\left(\mathrm{CHCl}_{3}\right) 3680,3600,2970,2940,2880,1725,1650,1605,1540,1510$.

HR FABMS gave $M H+$ at 1112.6511 (calculated 1112.6416 for $\mathrm{C}_{57} \mathrm{H}_{89} \mathrm{~N}_{7} \mathrm{O}_{5}$ ). The fragment ions at $\mathrm{m} / \mathrm{z} 1040,943$ and 816 corresponded to the sequential cleavage of the side chain, $\mathrm{m} / \mathrm{z} 861,771,743,686,555,307$ and 210 to the cleavage of the ring. In the MIKB spectrum of $\mathrm{m} / 2$ 1112, the large loss of $\mathrm{CO}$ indicated a cyclic peptdic structure. The aminoacid analysis was performed by CCMMS of the N-heptafluorobutyryl-O-propyl ester derivatives after hydrolysis by $6 \mathrm{~N} \mathrm{HCl}$ for $14 \mathrm{~h}$ at 110 ${ }^{\circ} \mathrm{C}$ in a sealed tube. The unusual aminoacids were characterized as follows : $\mathrm{N}-\mathrm{MeLeu}$ ( $\mathrm{EI}: \mathrm{m} / \mathrm{z} 296,100 \%, \mathrm{M}-87 ; \mathrm{m} / \mathrm{z} 254$, $30 \%$, loss of propene from $\mathrm{m} / \mathrm{z} 296 ; \mathrm{m} / \mathrm{z} 228,10 \%, \mathrm{C}_{3} \mathrm{~F}+\mathrm{CONH}\left(\mathrm{CH}_{3}\right) \mathrm{H}+; \mathrm{Cl}\left(\mathrm{CH}_{4}\right): \mathrm{m} / \mathrm{z} 384,40 \%, \mathrm{MH}+; \mathrm{m} / \mathrm{z} 324,100 \%$, loss of propanol; m/z 296, 80\%, loss of CO from m/z 324). MeTyr(Me) (EI : m/z 360, 7\%, M-87; m/2 220, 60\%, M - C ${ }_{3} \mathrm{~F}_{7}$ $\mathrm{CON}\left(\mathrm{CH}_{3}\right) \mathrm{H} ; \mathrm{m} / \mathrm{z} 121,100 \%, \mathrm{CH}_{3} \mathrm{OC}_{6} \mathrm{H}_{4} \mathrm{CH}_{2}+\mathrm{Cl}\left(\mathrm{CH}_{4}\right): \mathrm{m} / \mathrm{z} 448,40 \%, \mathrm{MH}+; \mathrm{m} / \mathrm{z} 388,100 \%$, loss of propanol; $\mathrm{m} / \mathrm{z}$ $360,80 \%$, loss of $\mathrm{CO}$ from m/z 388, $\mathrm{m} / \mathrm{z} 221,50 \%, \mathrm{MH}-\mathrm{C}_{3} \mathrm{~F}_{7} \mathrm{CON}\left(\mathrm{CH}_{3}\right) \mathrm{H}$; isoSta (EI : 552, 3\%, M - C $\mathrm{H}_{9}+\mathrm{m} / \mathrm{z} 510$, $10 \%$, loss of propene from $\mathrm{m} / \mathrm{z} 552 ; \mathrm{m} / \mathrm{z} 464,15 \%$, loss of propylformiate from $\mathrm{m} / \mathrm{z} 552 ; \mathrm{m} / \mathrm{z} 282,100 \%$, C-C cleavage between amino and hydroxylic functions; $\mathrm{Cl}\left(\mathrm{CH}_{4}\right): \mathrm{m} / \mathrm{z} 610,40 \%, \mathrm{MH}+; \mathrm{m} / \mathrm{z} 396,100 \%$, loss of $\mathrm{C}_{3} \mathrm{~F}_{7} \mathrm{COOH} ; \mathrm{m} / 2 \mathrm{z36}$, $80 \%$, loss of propanol from m/z 396, m/z 308, 40\%, loss of CO from m/z 336; m/z 282, 20\%, same origin as in the EI spectrum; $\mathrm{m} / \mathrm{z} 214,70 \%, \mathrm{C}_{3} \mathrm{~F}_{7} \mathrm{CONH}_{3}+$ ).

${ }_{1} \mathrm{H}$ NMR(in $\left.\mathrm{C}_{6} \mathrm{D}_{6}\right)$ : isosta: $7.54(\mathrm{NH}), 4.67(\mathrm{C} 4 \mathrm{H}), 2.33(\mathrm{C} 5 \mathrm{H}) 1.09\left(\mathrm{C}_{-}-\mathrm{CH}_{3}\right), 1.46-1.71\left(\mathrm{C} 6-\mathrm{H}_{2}\right), 1.16\left(\mathrm{C}-\mathrm{H}_{3}\right), 4.53$

$(\mathrm{C} 3 \mathrm{H}), 4.12\left(\mathrm{C}_{2}-\mathrm{H}_{2}\right)$

Leu:8.26(NH), 5.07 $(\alpha \mathrm{CH}), 1.05-1.07\left(\gamma \mathrm{C}-\mathrm{CH}_{3}\right)$;

Hip:4.54(C2H), 1.68(C2- $\left.\mathrm{CH}_{3}\right) 5.56(\mathrm{C} 4 \mathrm{H}), 2.48(\mathrm{C} 5 \mathrm{H}), 0.88-0.89\left(\mathrm{C}_{-}-\mathrm{CH}_{3}\right)$;

MeTyr(Me):2.20(NCH $)_{3}, 3.40(\alpha \mathrm{CH}), 3.23-3.36\left(\beta \mathrm{CH}_{2}\right), 6.72-6.82$ (Aromatics), $3.36\left(\mathrm{OCH}_{3}\right)$;

Thr:8.02(NH), 4.89( $\alpha \mathrm{CH}), 5.92(\beta \mathrm{CH}), 1.90\left(\beta \mathrm{C}-\mathrm{CH}_{3}\right)$;

DMeLeu:2.97( $\left(\mathrm{NCH}_{3}\right), 5.57(\alpha \mathrm{CH}), 1.98-1.70\left(\alpha_{\mathrm{CH}}\right), 1.05-1.07\left(\gamma \mathrm{C}-\mathrm{CH}_{3}\right)$;

Lactic-acid:4.27(CH), 1.38( $\left.\mathrm{CH}_{3}\right)$;

Prol:4.25( $\alpha \mathrm{CH}) 1.35\left(\beta_{\mathrm{CH}}\right), 1.27\left(\gamma \mathrm{CH}_{2}\right), 3.01-3.22\left(8 \mathrm{CH}_{2}\right)$;

Pro2:4,43( $\alpha \mathrm{CH}), 1.35\left(\mathrm{BCH}_{2}\right), 1.27\left(\mathrm{CH}_{2}\right), 2.55\left(8 \mathrm{CH}_{2}\right)$.

Alcaline hydrolysis of didemnin: $5 \mathrm{mg}$ of didemnin (our sample or isodidemnin-1) were solubilized in cooled $\left(5^{\circ} \mathrm{C}\right.$ ) methanol 
$(100 \mu l)$ and $1 \mathrm{~N} \mathrm{NaOH}(20 \mu l)$ was added. After $30 \mathrm{~min}$., $1 \mathrm{~N} \mathrm{HCl}(20 \mu 1)$ was added followed by $\mathrm{CH}_{2} \mathrm{~N}_{2}$ until persistent yellow coloration. The solvent was removed under a stream of argon and the crude residue was applied on a short silica gel column (5g) and eluted with $\mathrm{MeOH} / \mathrm{CH}_{2} \mathrm{Cl}_{2}$ (8/92). After evaporation by bubbling argon of the major fraction $\left(\mathrm{Rf}^{0.33} \mathrm{CH}_{2} \mathrm{Cl}_{2}\right.$ MeOH 95/5), the peptide was further purified by HPLC (MeOH/Water 75/25) column A; analysis HPLC column B (MeOH, 1\% TFA $/ \mathrm{H}_{2} \mathrm{O}, 1 \%$ TFA 50/50)tr-6.15mn. Methanol was removed under rectuced pressure and the remaining water solution was freezed and lyophilized.

Synthesis: Acetyl - lactyl - proline tert-butyl ester (1): BOP (17.68 g, $40 \mathrm{mmol}$ ) and DIEA (diisopropylethyl amine, $6.9 \mathrm{ml}$, $40 \mathrm{mmol}$ ) were stirred with a solution of acetyl-lactic acid $(5.28 \mathrm{~g}, 40 \mathrm{mmol})$ and of proline tert-butyl ester $(3.42 \mathrm{~g}, 20 \mathrm{mmol})$ in methylene chloride $(50 \mathrm{ml})$. After $2 \mathrm{~h}$ at room temperature, the reaction mixture was diluted with EtOAc $(150 \mathrm{mi})$ and washed with $\mathrm{KHSO}_{4} 5 \%(2 \times 30 \mathrm{ml})$, then with $\mathrm{Na}_{2} \mathrm{CO}_{3} 5 \%(2 \times 30 \mathrm{ml})$ and saturated $\mathrm{NaCl}(30 \mathrm{ml})$. The mixture was drled over $\mathrm{Na}_{2} \mathrm{SO}_{4}$, filtered and concentrated under reduced pressure. Chromatographic purification (open column of silica gel with ethyl acetate/hexane $50 / 50$ as solvent mixture) yielded $5.30 \mathrm{~g}(93 \%)$ of $(1)$ as a coloriess oil. $[\alpha]_{\mathrm{D}^{-}}-120^{\circ}(\mathrm{c} 1, \mathrm{MeOH})$; ${ }^{1} \mathrm{H}$ NMR $\left(\mathrm{DMSO}_{6}\right) 5.13(\mathrm{q}, \mathrm{J}=6.8 \mathrm{~Hz}, 1 \mathrm{H}), 4.17$ (dd, $\mathrm{J}=5.2$ and $\left.8.6 \mathrm{~Hz}, 1 \mathrm{H}\right), 3.66-3.57(\mathrm{~m}, 1 \mathrm{H}), 3.53-3.43(\mathrm{~m}, 1 \mathrm{H})$, 2.21-2.08 (m,1H), $2.02(\mathrm{~s}, 3 \mathrm{H}), 1.97-1.87(\mathrm{~m}, 1 \mathrm{H}), 1.37(\mathrm{~s}, 9 \mathrm{H}), 1.32(\mathrm{~d}, \mathrm{~J}=6.8 \mathrm{~Hz}, 3 \mathrm{H})$. Anal. Calod. for $\mathrm{C}_{14} \mathrm{H}_{23} \mathrm{NO}_{5}$ : C, 58.93; H, 8.12; N, 4.91. Found: C, 58.80; H, 8.10; N, 5.05.

Acetyl - lactyl proline (2) : $(11.98 \mathrm{~g}, 42 \mathrm{mmol})$ was stirred in trifluoroacetic acid $(20 \mathrm{ml})$ at room temperature for $2 \mathrm{~h}$. After removing the solvent under reduced pressure, (2) was crystaltised by triturating in diethyl ether $(7.02 \mathrm{~g} .73 \%)$. $\mathrm{mp} 146-$ $148^{\circ} \mathrm{C} ;[\alpha]_{\mathrm{D}}=-114^{\circ}(\mathrm{c} 1, \mathrm{MeOH}) ;{ }^{1} \mathrm{H}$ NMR $\left(\mathrm{DMSO} \mathrm{d}_{6}\right) 5.14(\mathrm{q}, \mathrm{J}=6.9 \mathrm{~Hz}, 1 \mathrm{H}), 4.25(\mathrm{dd}, \mathrm{J}=5.2$ and $9.5 \mathrm{~Hz}, 1 \mathrm{H}), 3.66-$ $3.56(\mathrm{~m}, 1 \mathrm{H}), 3.56-3.45(\mathrm{~m}, 1 \mathrm{H}), 2.24-2.06(\mathrm{~m}, 1 \mathrm{H}), 2.02(\mathrm{~s}, 3 \mathrm{H}), 1.98-1.88(\mathrm{~m}, 1 \mathrm{H}), 1.88-1.78(\mathrm{~m}, 1 \mathrm{H}), 1.31(\mathrm{~d}, \mathrm{~J}=$ $6.9 \mathrm{~Hz}, 3 \mathrm{H}$ ). Anal. Calcd. for $\mathrm{C}_{10} \mathrm{H}_{15} \mathrm{NO}_{5}$ : C, 52.40; H, 6.60; N, 6.11. Found: C, 52.60; H, 6.75; N, 6.00.

[N,N-(benzyloxycarbonyl)-methyl-D-leucyl] - threonine methyl ester (3): BOP (6.63 g, $15 \mathrm{mmol}$ ) and DIEA (5.7 ml, $15 \mathrm{mmol}$ ) were added to $\mathrm{CH}_{2} \mathrm{Cl}_{2}$ solution $(20 \mathrm{ml})$ of threonine methyl ester $(2.54 \mathrm{~g}, 15 \mathrm{mmol})$ and of $\mathrm{Z}$-(NMe)-D-leucine $(4.19 \mathrm{~g} .15 \mathrm{mmol}$ ) - prepared from Z-D-leucine according to McDermott and Benoiton [26] - . The work-up already described for (1) afforded crude (3) as a colorless oil (5.73 g, 97\%).[ $\alpha]_{\mathrm{D}}=+40^{\circ}$ (c $\left.1, \mathrm{MeOH}\right) ;{ }^{1} \mathrm{H} \mathrm{NMR}$ (DMSO d $)_{6} 7.74$ (m, $1 \mathrm{H}), 7.40-7.26(\mathrm{~m}, 5 \mathrm{H}), 5.13(\mathrm{~s}, 2 \mathrm{H}), 4.95(\mathrm{~m}, 1 \mathrm{H}), 4.89-4.68(\mathrm{~m}, 1 \mathrm{H}), 4.30$ (dd, $\mathrm{J}=2.0$ and $9.5 \mathrm{~Hz}, 1 \mathrm{H}), 3.62(\mathrm{~s}, 3 \mathrm{H})$, $2.80(\mathrm{~s}, 3 \mathrm{H}), 1.64-1.56(\mathrm{~m}, 2 \mathrm{H}), 1.48-1.34(\mathrm{~m}, 1 \mathrm{H}), 1.05(\mathrm{~d}, \mathrm{~J}=7.7 \mathrm{~Hz}, 3 \mathrm{H}), 0.94-0.78(\mathrm{~m}, 6 \mathrm{H})$. Anal. Calcd. for $\mathrm{C}_{20} \mathrm{H}_{30} \mathrm{~N}_{2} \mathrm{O}_{6}: \mathrm{C}, 60.90 ; \mathrm{H}, 7.67 ; \mathrm{N}, 7.10$. Found: $\mathrm{C}, 60.75 ; \mathrm{H}, 7.82 ; \mathrm{N}, 7.25$.

Acetyl - lactyl - prolyl - [(N-methyl)-D-leucyl] - threcnine methyl ester (4): To a solution of (3) (3.94 g, $10 \mathrm{mmol})$ in $\mathrm{MeOH}(50 \mathrm{ml})$ were added $1 \mathrm{~N} \mathrm{HCl}(12 \mathrm{ml})$ and palladium $10 \%$ on charcoal $(0.9 \mathrm{~g})$. The mixture was stirring for $1 \mathrm{~h}$ at room temperature with bubbling hydrogen. The catalystwas then fittered off and the solvent evaporated in vacuo. The resulting amino hydrochloride was crystallised in MeOH/diethyl ether $-2.58 \mathrm{~g}, 87 \% ; \mathrm{mp} 211-212^{\circ} \mathrm{C} ;[\alpha] \mathrm{D}^{-1}-52^{\circ}$ (c $\left.1, \mathrm{MeOH}\right)-$. Freshly prepared and finely ground $[27] \mathrm{BOP}-\mathrm{Cl}(2.20 \mathrm{~g}, 8.6 \mathrm{mmol})$ was added with triethyiamine $(1.21 \mathrm{ml}, 8.6 \mathrm{mmol})$ to a solution of (2) $-1.98 \mathrm{~g}, 8.6 \mathrm{mmol}$ in $\mathrm{CH}_{2} \mathrm{Cl}_{2}(10 \mathrm{ml})$-. The mixture was stirred at room temperature until BOP-Cl was solubilized $(2 \mathrm{~h})$. D-MeLeu-Thr-OMe, $\mathrm{HCl}(2.56 \mathrm{~g}, 8.6 \mathrm{mmol})$ was then added with triethylamine $(1.21 \mathrm{ml}, 8.6 \mathrm{mmol})$ and the resulting mixture stirred overnight. The aforementioned work-up [see (1)] furnished crude (4) which was purified by cristallisation in diethyl ether $(2.92 \mathrm{~g}, 72 \%) ; \mathrm{mp} 169-170^{\circ} \mathrm{C} ;[\alpha] \mathrm{D}^{-+12^{\circ}}(\mathrm{c} 1, \mathrm{MeOH}) ;{ }^{1} \mathrm{H}$ NMR (DMSO d 6 ) $7.38(\mathrm{~d}, \mathrm{~J}=8.3 \mathrm{~Hz}$, $1 \mathrm{H}), 5.21(\mathrm{q}, \mathrm{J}=6.8 \mathrm{~Hz}, 1 \mathrm{H}), 5.16(\mathrm{dd}, \mathrm{J}=4.4$ and $9.8 \mathrm{~Hz}, 1 \mathrm{H}), 4.87(\mathrm{~d}, \mathrm{~J}=9.3 \mathrm{~Hz}, 1 \mathrm{H}), 4.80(\mathrm{~d}, \mathrm{~J}=7.8 \mathrm{~Hz}, 1 \mathrm{H})$, $4.29(\mathrm{dd}, \mathrm{J}=3.4$ and $8.3 \mathrm{~Hz}, 1 \mathrm{H}), 4.18-4.07(\mathrm{~m}, 1 \mathrm{H}), 3.81-3.73(\mathrm{~m}, 1 \mathrm{H}), 3.63(\mathrm{~s}, 3 \mathrm{H}), 3.55-3.42(\mathrm{~m}, 1 \mathrm{H}), 3.00(\mathrm{~s}, 3 \mathrm{H})$, 2.29-2.17 (m, 1H), 2.12-1.85 (m, 2H), $2.01(\mathrm{~s}, 1 \mathrm{H}), 1.75-1.47(\mathrm{~m}, 3 \mathrm{H}), 1.43-1.33(\mathrm{~m}, 1 \mathrm{H}), 1.30(\mathrm{~d}, \mathrm{~J}=6.8 \mathrm{~Hz}, 3 \mathrm{H})$, $1.07(\mathrm{~d}, \mathrm{~J}=6.7 \mathrm{~Hz}, 3 \mathrm{H}), 0.89(\mathrm{~d}, \mathrm{~J}=6.2 \mathrm{~Hz}, 3 \mathrm{H}), 0.81(\mathrm{~d}, \mathrm{~J}=6.2 \mathrm{~Hz}, 3 \mathrm{H})$. Anal. Calcd. for $\mathrm{C}_{22} \mathrm{H}_{37} \mathrm{NO}_{\mathrm{g}}: \mathrm{C}, 56.04 ; \mathrm{H}$, $7.91 ; \mathrm{N}, 8.91$. Found: $\mathrm{C}, 55.79 ; \mathrm{H}, 7.82 ; \mathrm{N}, 8.96$.

Lactyl - prolyl - [(N-methyl)-D-leucyl] - threonine (5): 1N NaOH (15 ml) was added dropwise to a cold solution of (4) $2.36 \mathrm{~g}, 5 \mathrm{mmol}$ - in $\mathrm{MeOH}(10 \mathrm{ml})$ and stirred for $20 \mathrm{~min}$. Then $1 \mathrm{~N} \mathrm{HCl}(15 \mathrm{ml})$ was added and the solvent evaporated under rectuced pressure. The clear solution was satured with $\mathrm{NaCl}$ and extracted four times with $\mathrm{CH}_{2} \mathrm{Cl}_{2}(20 \mathrm{ml}$ ). The combined organic layers were dried over $\mathrm{Na}_{2} \mathrm{SO}_{4}$, filtered and concentrated. (5) was crystallized by triturating in diethyl ether $(2.00 \mathrm{~g}$, $96 \%$ ); $\mathrm{mp} 158-159^{\circ} \mathrm{C} ;[\alpha]_{D}+56^{\circ}$ (c 1, MeOH). Anal. Calod for $\mathrm{C}_{19} \mathrm{H}_{33} \mathrm{~N}_{3} \mathrm{O}_{7}$ : C, 54.93; $\mathrm{H}, 8.01 ; \mathrm{N}, 10.11$. Found: $\mathrm{C}$, $55.09 ; \mathrm{H}, 7.92 ; \mathrm{N}, 9.96$.

Lactyl - propyl - [(N-methyl)-D-leucyl] - threonyl - (3R,4S,5S)- isostatin methyl ester (6a): Coupling between (5) - 0.91 $\mathrm{g}, 2.2 \mathrm{mmol}$ - and the trifluoroacetate salt of the $(3 \mathrm{R}, 4 \mathrm{~S}, 5 \mathrm{~S})$-isostatin ethyl ester - $0.63 \mathrm{~g}, 2 \mathrm{mmol}$ - was accomplished in the same conditions already described for (3) and afforded the corresponding pepude as a foam $(1.10 \mathrm{~g})$. This crude restdue was saponified to furnish the acid $(0.9 \mathrm{~g})$ which was promptly solubilized in $\mathrm{MeOH}$ and treated with $\mathrm{CH}_{2} \mathrm{~N}_{2}$ until persistent yellow colour. After the solvent was removed, the residue was purified by low pressure chromatography on a Lowbar column

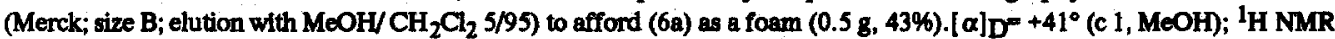
(see table 2). Anal. Calcd. for $\mathrm{C}_{28} \mathrm{H}_{50} \mathrm{~N}_{4} \mathrm{O}_{9}$ : C, 57.32; H, 8.59; N, 9.55. Found: C, 57.05; H, 8.65; N, 9.70. HPLC column B (MeoH, 1\%TFA/Water, 1\%TFA 50/50) trm6.14mn. TLC Rf 0.33, $\mathrm{CH}_{2} \mathrm{Cl}_{2} / \mathrm{MeOH} 95 / 5$.

Lactyl - prolyl - [(N-methyl)-D-leucyl] - threonyl - (3S,4R,5S) - isoatatin methyl ester (6b): By a similar procedure, (6b) was obtained as a foam $(0.47 \mathrm{~g}, 40 \%),[\alpha]_{D^{-}}+36^{\circ}(\mathrm{c} 1, \mathrm{MeOH}) ;{ }^{1} \mathrm{H}$ NMR (see table 2). Found for $\mathrm{C}_{28} \mathrm{H}_{50} \mathrm{~N}_{4} \mathrm{O}_{9}: \mathrm{C}$, 57.06; H, 8.69; N, 9.48. HPLC column B (MeOH, 1\%TFA/Water, 1\%TFA 50/50) tr=8.49mn. TLC Rf 0.27, $\mathrm{CH}_{2} \mathrm{Cl}_{2}$ l MeOH 95/5. 


\section{Acknowledgements}

This research was aupported by INSBRM Grants ( $n^{\circ} 841005$ and 841014). We have to thank M.Guyot for a generous gift of isodidemnin-1. We would like to thank the Service de microanalyses du C.N.R.S. ( Ecole Nationale Superieure de Chimie de Montpellier) for elemental analysis results and SANOFI-RBCHERCHES (Toulouse) for pharmacological screenings.

\section{REFERENCES}

1 (a) C.Ireland and P.J.Schever, J.Am.Chem.Soc., 1980, 102,5688 ; (b) K.L.Rinehart, J. B. Gloer, R.G.Hugues, H.E .Denis, P.J. MeGovren, E.G.Swynenberg, D.A.Stringfellow, S.L. Kuentzel and H.L. Li, Science, 1981, 212,933 ; (c) C.Ireland, A.R.Durso, R.A.Newman and M.P. Hacker, J.Org.Chem, 1982, 47, 1807 ; (d) M.Guyot, C.Belaud and E. Morel, J.Chem. Res. (S), 1983, 188 and $(M), 1823$; (e) D.Gouiffes, S.Moreau, N.Helbecque, J.L.Bernier, J.P. Hénichart, Y.Barbin, D.Laurent, J.F.Verbist, Tetrahedron 1988, 44, 451 ; (f) K.L.Rinehart, V. Kishnou, K.C.Bibli, R.Sakai, D.W . Sullins,K.M.Li, J.Nat.Prod., 1988, 51, 1 .

2 F.Lafargue and M.Wahl, Ann.Inst.Oceanogr, 1987, 63 (l), 1.

3 K.L.Rinehart, P.D.Shaw, L.S.Shield, J.B.Gloer, G.C.Harbour,M.E.S. Koker, D.Samain, R.E.Schwartz, A.A.Tymiak, D.L.Weller, M.H.G.Munro, G.T.Carter, R.G.Hugues, H.E. Renis, E.B.Swynenberg, H.L.Li, D.A. Stringfellow, J.J. Vavra, J.H.Coats, G.E.Zurenko, S.L.Kuentzel, G.J. Bakus, R.C.Brusca, L.L.Craft, D.N.Young and J.L.Connor, Pure Appl. Chem., 1981, 53, 795.

4 J.B.Gloer, Ph.D.thesis (1983), University of Illinois.

5 K.L.Rinehart, J.B.Gloer, J.C.Cook, S.A.Mizsak ,T.A.Scahill, J.Am.Chem.SoC., 1981, $103,1857$.

6 (a)T.J.Jiang, R.H.Liu, S.E.Salmon, CancerChemother. Pharm., 1983, 11,1 ; (b)L.H.Li, L.G.Timmins, T.L.Wallace, W.C.Krueger, M.D. Prairie, W.B.Im, CancerLettets, 1984, 23, 279 ;(c)S.L.Crampton, E.G.Adams, S.L.Kuentzel, L.H. Li, G.Badiner, B.J.Bhuyan, Cancer Rex, 1984, 44, 1796 ; (d)D.W.Montgomery and C.F. Zukosky, Transplantation 1985, 40, 49;(e) H.G.Chun, B.Davies, D.Hoth, M.Suffness, J. Plowman, K. Flora, C.Grieshaber, B.Leyland-Jones, Investigat. New Drugs, 1986, 4, 279 .

7 M.Guyot, D.Davoust, E.Morel, C.R.Acad.Sci., 1987, 305, 681.

8 K.L.Rinehart, V.Kishore, S.Nagarayan, R.J.Lake,J.B.Gloer, K.Li, F.A.Bozich, R.E. Maleczka, W.L.Todsen, M.H.G. Munro, D.W.Sullins, R. Sakai, J.Am.Chem.Soc., 1987, 109, 6846.

9 M.Wahl, Ph.D.thesis(1987), University of Kiel .

10 F.Lafargue and G.Duclaux, Ann.Inst. Oceanogr, 1979, 55(2), 163.

11 B.Castro, P.Jouin, A.Cave, M.Dufour, B.Banaigs, C.Francisco in "Peptides Chemistry and Biologie", Proceedings of the 10th American Peptide Symposium, G.R.Marshall Ed., 1988, Leiden, 656.

12 (a)W.P.Aue,E.Bartholdi,R.R.Brnst, J.Chem.Phys., 1976, 64, 2229; (b)G. Bodenhausen, R.Freeman, J.Magn.Reson., 1977, 28, 471;(c)A.Bax,F.Mehlkoph,J.Smidt, J.Magn.Reson., 1980, 40, 213;(d) A.Bax, R. Freeman, J.Magn.Reson., $1981,44,542$.

13 (a)J.Jeener, B.H.Meier, P.Bachmann, R.R.Ernst, J.Chem.Phys., 1979, 69, 4546 ; (b)S.Macura, Y.Huang, D.Suter, R.R.Ernst, J.Magn.Reson., 1981, 43, 259 .

14 W.R.Ewing, K.L.Bhat, M.M.Joullié, Tetrahedron, 1986, 42, 5863.

15 P.Marfey, Carisberg Res.Commun., 1984, 49, 591.

16 B.Banaigs, G.Jeanty, J.M.Aracil, C.Francisco, J.ofChromatography(submitted to publication).

17 K.L.Rinehart, 10th American Peptide Symposium, St.Louis, May 23-28, 1987.

18 (a)B.Castro, J.R.Dormoy,J.G.Evin, C.Selve, Tetrahedron Lett., 1975, 1219;(b)P.Rivaille, J.P. Gaudron, B.Castro, G.Milhaud, Tetrahedron 1980, 36, 3413;(c)R.M.Wenger, Helv.Chim.Acta, 1983, 66, 2672;(d)J.A.Ferhentz, R.Seyer, A.Heitz, P.Fulcrand, B.Castro, P.Corvol, Int. J. Pept. Protein Res., 1986, $28,620$.

19 C.Van Der Auwera, M.J.O.Anteunts, Int.J.Peptide Proteln Res., 1987, 29, 574.

20 P.Jouin, J.Poncet, M.N.Dufour, I.Maugras, A.Pantaloni, B.Castro, Tetrahedron Lett, 1988, 2661.

21 H.R.Loosli, H.Keader, H.Oachkinat, H.P.Weber, T.J.Petcher, A. Widmer, Helv. Chim. Acta, 1985, 68, 682. 22 R.Chandrasekaran, A.Lakahminarayan, U.Pandya, G.Ramachandran, Blochim. Blophys. Acta, 1973, $303,14$. 23 (a)L.G.Pease, C.H.Nin, G.J.Zimmermann, J.Am.Chem.Soc, , 1979, 101, 184; (b) E.S. Stevens, N.Sugawara, G.M. Bonara, C.Toniolo, J.Am. Chem. Soc, $1980,102,7048$.

24 W.S.Liu, S.C.Smith, G.I.Glover, J.Med.Chem., 1979, 22, 577.

25 G.R.Pettit, Y.Kamano, C.L.Herald, A.A.Tutnman, F.E.Boetmer, H.Kizu, J.M.Schmidt, L.Baczynskyj, K.B.Tomer, R.J.Bontems, J.Am. Chem.Soc., 1987, 109, 6883.

26 J.R.McDermott, N.L.Benoiton, Can.J.Chem., 1973, 51, 1915.

27 C.Van der Auwera, M.J.O.Anteunis, Bull.Soc.Chim.Belg., 1986, 95, 203. 